\title{
Operational Restoration of the Pen Branch Bottomland Hardwood and Swamp Wetlands - The Research Setting
}

by

E. A. Nelson

Westinghouse Savannah River Company

Savannah River Site

Aiken, South Carolina 29808

N. C. Dulohery

R. K. Kolka

W. H. McKee Jr.

A document prepared for JOURNAL ARTICLE - ECOLOGICAL ENGINEERING at , , from - .

DOE Contract No. DE-AC09-96SR18500

This paper was prepared in connection with work done under the above contract number with the U.S.

Department of Energy. By acceptance of this paper, the publisher and/or recipient acknowledges the U. S. Government's right to retain a nonexclusive, royalty-free license in and to any copyright covering this paper, along with the right to reproduce and to authorize others to reproduce all or part of the copyrighted paper. 


\section{DISCLAIMER}

This report was prepared as an account of work sponsored by an agency of the United States Government. Neither the United States Government nor any agency thereof, nor any of their employees, makes any warranty, express or implied, or assumes any legal liability or responsibility for the accuracy, completeness, or usefulness of any information, apparatus, product or process disclosed, or represents that its use would not infringe privately owned rights. Reference herein to any specific commercial product, process or service by trade name, trademark, manufacturer, or otherwise does not necessarily constitute or imply its endorsement, recommendation, or favoring by the United States Government or any agency thereof. The views and opinions of authors expressed herein do not necessarily state or reflect those of the United States Government or any agency thereof.

This report has been reproduced directly from the best available copy.

Available for sale to the public, in paper, from: U.S. Department of Commerce, National Technical Information Service, 5285 Port Royal Road, Springfield, VA 22161

phone: (800) 553-6847

fax: (703) 605-6900

email: orders@ntis.fedworld.gov

online ordering: http://www.ntis.gov/ordering.htm

Available electronically at http://www.doe.gov/bridge

Available for a processing fee to U.S. Department of Energy and its contractors, in paper, from: U.S. Department of Energy, Office of Scientific and Technical Information, P.O. Box 62, Oak Ridge, TN 37831-0062

phone: (865)576-8401

fax: (865)576-5728

email: reports@adonis.osti.gov 


\section{DISCLAIMER}

Portions of this document may be illegible in electronic image products. Images are produced from the best available original document. 
WSRC-TR-99-00407

October 25, 1999

OPERATIONAL RESTORATION OF THE PEN BRANCH BOTTOMLAND HARDWOOD AND SWAMP WETLANDS-THE RESEARCH SETTING

Eric A. Nelson ${ }^{1}$, Neil C. Dulohery ${ }^{2}$, Randall K. Kolka ${ }^{3}$, William H. McKee Jr.4

1 Savannah River Technology Center, Westinghouse Savannah River Company, Aiken, South Carolina 29808

2 Forest Research Center, Jefferson Smurfit Corporation, PO Box 626, Callahan, Florida 32011

${ }^{3}$ Department of Forestry, University of Kentucky, Lexington, Kentucky 40546

4 US Forest Service (retired), 501 King Rd., Dunlap, Tennessee 37327

Address correspondence to (EAN): Phone: (803) 725-5212; FAX (803) 725-7673;

E-mail: eric.nelson@srs.gov

\begin{abstract}
The Savannah River Swamp is a 3020 Ha forested wetland on the floodplain of the Savannah River and is located on the Department of Energy's Savannah River Site (SRS) near Aiken, SC. Historically the swamp consisted of approximately $50 \%$ bald cypresswater tupelo stands, $40 \%$ mixed bottomland hardwood stands, and $10 \%$ shrub, marsh, and open water. Creek corridors were typical of Southeastern bottomland hardwood forests. The hydrology was controlled by flooding of the Savannah River and by flow from four creeks that drain into the swamp prior to flow into the Savannah River. Upstream dams have caused some alteration of the water levels and timing of flooding within the floodplain.
\end{abstract}

Major impacts to the swamp hydrology occurred with the completion of the production reactors and one coal-fired powerhouse at the SRS in the early 1950's. Water was 
WSRC-TR-99-00407

October 25, 1999

pumped from the Savannah River, through secondary heat exchangers of the reactors, and discharged into three of the tributary streams that flow into the swamp. Flow in one of the tributaries, Pen Branch, was typically $0.3 \mathrm{~m}^{3} \mathrm{~s}^{-1}(10-20) \mathrm{cfs}$ prior to reactor pumping and $11.0 \mathrm{~m}^{3} \mathrm{~s}^{-1}(400 \mathrm{cfs})$ during pumping. This continued from 1954 to 1988 at various levels. The sustained increases in water volume resulted in overflow of the original stream banks and the creation of additional floodplains. Accompanying this was considerable erosion of the original stream corridor and deposition of a deep silt layer on the newly formed delta. Heated water was discharged directly into Pen Branch and water temperature in the stream often exceeded 65 degrees $C$. The nearly continuous flooding of the swamp, the thermal load of the water, and the heavy silting resulted in complete mortality of the original vegetation in large areas of the floodplain.

In the years since pumping was reduced, early succession has begun in some affected areas. Most of this has been herbs, grasses, and shrubs. Areas that have seedlings are generally willow thickets that support a lower diversity of wildlife. No volunteer seedlings of heavy-seeded hardwoods or cypress have been found in the corridor areas. Research was conducted to determine methods to reintroduce tree species characteristic of more mature forested wetlands. Three restoration strategies were formulated to deal with the differing conditions of the Upper Corridor, the Lower Corridor, and the Delta regions of the impacted area. Site preparation and planting of each area with mixtures of tree species were carried out to speed the restoration of the ecosystem. Species

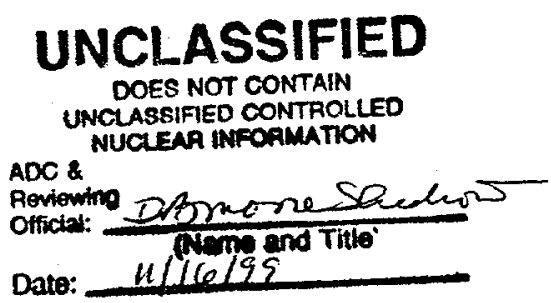


WSRC-TR-99-00407

October 25, 1999

composition and selection were altered based on the current and expected hydrological regimes that the reforestation areas will be experiencing.

Because of the operational design of the restoration project, a research program naturally followed to document the success. Many of those efforts are detailed here.

\section{KEYWORDS}

Wetland restoration, Pen Branch, mitigation, bottomland hardwoods, site preparation, planting, riparian and swamp habitats

\section{INTRODUCTION}

Pen Branch is a small, 3rd order stream whose watershed lies entirely within the boundaries of the Savannah River Site (SRS), a U.S. Department of Energy (DOE) nuclear materials facility (Figure 1). Pen Branch flows into the Savannah River swamp, a mosaic of bottomland-hardwood and cypress-tupelo forests. Between 1950 and 1954, the DOE constructed a nuclear reactor, $\mathrm{K}$ Reactor, adjacent to a first order tributary of Pen Branch, Indian Grave Creek. Heat was dissipated from the reactor's internal closed-loop cooling system by pumping water from the Savannah River across a heat exchanger, eventually discharging the heated water into Indian Grave Creek. 
WSRC-TR-99-00407

October 25, 1999

K Reactor began discharging thermal effluent into the Indian Grave / Pen Branch system in 1954. The reactor's contribution to streamflow varied temporally, but was consistently 1 to 2 orders of magnitude greater than the stream's base flow of $0.3 \mathrm{~m}^{3} \mathrm{~s}^{-1}$ (Figure 2). The average annual temperature of the effluent varied up to a maximum of $70^{\circ} \mathrm{C}$. Thermal discharges ended in 1989. At present, non-heated water is being added at the rate of about $0.006 \mathrm{~m}^{3} \mathrm{~s}^{-1}$, or less than $5 \%$ of the estimated base flow rate.

In 1951, the Savannah River Swamp and Pen Branch corridor was a closed canopy forests. During the early years of reactor operation, as temperatures and outflow rates increased, flooding and scalding progressively deforested the corridor. By 1961, canopy defoliation was apparent throughout 113 ha of the corridor and 4.5 ha of the delta (Wike et al., 1994). From 1961 to 1989, the thermal effluent gradually denuded a fanshaped delta in the Savannah River swamp forest and a narrow "tail" of concentrated flow to the southeast toward Steel Creek, near the swamp's upland boundary (Figure 3). The area of severe canopy loss in the delta reached its maximum extent of about 152 ha in the mid-1980's (Wike et al., 1994). Due to the inflow of water from Pen Branch, the delta area had been poorly drained even before 1951, supporting a cypress-tupelo swamp surrounded by more elevated mixed bottomland hardwood areas.

As the thermal discharges and flooding declined after 1988, early-successional plants rapidly colonized the corridor and delta. By the early 1990's, dense thickets of black willow (Salix nigra), with minor elements of black alder (Alnus serrulata), wax myrtle 
WSRC-TR-99-00407

October 25, 1999

(Myrica cerifera), button bush (Cephalanthus occidentalis), and sumac (Rhus sp.) occupied much of the upper corridor. A few red maple (Acer rubrum) were present, but there was virtually no regeneration of other species typically present as large canopy trees in mature bottomland forests. These species failed to regenerate because the prolonged thermal discharges had eliminated seed sources and living root stocks from the floodplain - and there were few hydrophytic trees in the adjacent uplands.

Natural regeneration was also scant in the delta. Even after the thermal discharges had ceased, most of the delta remained continuously flooded and was colonized by a mixture of cattails (Typha latifolia) and bulrush (Scirpus sp.). Continuous flooding precluded germination of bald cypress (Taxodium distichum) and water-tupelo (Nyssa aquatica) seeds, which may have disseminated into the area. Dry periods are required for widespread seed germination in cypress/tupelo swamps. Sharitz and Lee (1985) have attributed some forest regeneration failures in the Savannah River floodplainwhere the Pen Branch Delta is located - to the absence of historically frequent dry periods after the installation of dams upstream on the Savannah River. Sediment deposition during reactor operations may also have altered the delta's hydrology.

\section{REFORESTATION OBJECTIVES}

As a result of an environmental impact statement concerning, in part, continued operation of K Reactor, the DOE (1991) decided to mitigate impacts both from potential 
WSRC-TR-99-00407

October 25, 1999

thermal discharges before completion of a cooling tower and from continued discharges at ambient stream temperatures. In a record of decision published in the Federal Register, the DOE (1991) targeted 69 ha of land in the Indian Grave / Pen Branch Corridor and 202 ha in the Pen Branch delta for mitigation due to historical impacts. Westinghouse Savannah River Company subsequently developed a mitigation strategy (Nichols, 1992).

The primary mitigation objective was to accelerate the establishment of wetlands that had adversely been impacted by the reactor operations. This would entail the return of a bottomland-hardwood ecosystem in the Pen Branch corridor and a cypress-tupelo ecosystem in the delta. As a result of that effort, the functionality of the wetland ecosystem would be re-established and the biodiversity of the area would be increased to natural levels. In developing specific mitigation objectives, two constraints were agreed upon among the parties involved:

1) Only those areas judged not to be revegetating satisfactorily would be replanted with indigenous bottomland tree species appropriate for the local soils and hydrology (Nichols, 1992).

2) Some portions of the corridor and delta would remain in non-treated control strips to a) provide reference areas to judge the effectiveness of mitigation 
WSRC-TR-99-00407

October 25, 1999

measures, b) enhance scientific interest in the project, and c) leave some habitat in an early succession state for certain wildlife species.

\section{PROJECT-AREA BOUNDARIES}

The northern boundary of the Pen Branch restoration is a powerline right-of-way crossing Pen Branch about $200 \mathrm{~m}$ south of Risher Pond Road (SRS Rd. A-13.2). From this point northward to K Reactor, the floodplain was sufficiently well drained to permit regeneration of facultative wetland tree species present in the adjacent uplands. The area targeted for artificial regeneration included a stream reach $2.5 \mathrm{~km}$ in length with a floodplain varying in width from 100 to $300 \mathrm{~m}$, and a denuded delta region into which Pen Branch flows. About 53 ha along the fringes of this delta were regenerating naturally with bald cypress and water tupelo (Figure 1).

The boundary between the naturally-regenerating and more deficient areas of the delta was determined by ground reconnaissance and visual inspection. Aerial photographs were of little use in locating natural regeneration in this area due to a lack of distinctive patterns or shading, and the small size of the seedlings. A variety of regeneration was present in the fringe, including seedlings, saplings and recovering snags. Densities varied considerably but were judged to be sufficient for the development of a closed canopy forest. The natural regeneration boundary was usually distinct, with virtually no volunteer seedlings in the continuously flooded central delta 
WSRC-TR-99-00407

October 25, 1999

Within the artificial-regeneration area, 3 treatment zones were identified (Figure 1), based upon the differing species mixtures and silvicultural treatments required for the conditions of each zone (Table 1). The areas differed in hydrology (Figure 4) and species and density of current vegetation. The Upper Corridor was a mesic bottomland vegetated with dense black willow stands, the Lower Corridor was a poorly drained bottomland and vegetated by grasses and herbs, and the Delta was a swamp vegetated by cattails and bulrushes with some scattered willow on ridges.

Twenty-five percent ( $21 \mathrm{ha}$ ) of the total artificial regeneration area ( $85 \mathrm{ha}$ ) was reserved in 8 non-treated, non-planted control strips (Figure 1). These were established several months before planting in each section by placing pin flags along the boundaries and clearing all vegetation in $5 \mathrm{~m}$ wide swaths across the corridor. These areas would serve as untreated, unplanted controls to continue the natural recovery timetable for the ecosystem and assess the impact of active restoration.

The boundaries between areas were initially maintained by annual clearing and herbicide application. However, in 1995-96, the boundaries were monumented with high-visibility markers and cleared only where necessary for access. At both ends of each control line (upland/floodplain boundary in the corridor), is a $13 \mathrm{~cm}$ diameter white PVC pipe, $2 \mathrm{~m}$ in height. At the base of each pipe, is a steel bar with at least $50 \mathrm{~cm}$ above ground for relocation in case of fire. End points of control lines in the delta were 
WSRC-TR-99-00407

October 25, 1999

marked with $13 \mathrm{~cm}$ diameter piping, 3 to $4 \mathrm{~m}$ in height. Adjacent to each pipe is a grooved aluminum pipe, 1 to $2 \mathrm{~m}$ in height for relocation in case of fire.

\section{SITE PREPARATION AND PLANTING}

The sites were prepared and planted during the period from winter 1992-93 the winter 1994-95 (Table 2). The lower corridor was planted in February and March of 1993, the upper corridor in January of 1994, and the delta in January and February of 1995. Also in 1995, the upper and lower corridors were inter-planted to compensate for mortality, which was revealed in the 1994 stocking survey (discussed later). For each area, site preparation and species mixtures were varied to suit local conditions. Each year's activities are described below.

Winter 1992-93

Only the lower corridor was planted in the winter of 1992-93. In this area, there were frequent grassy openings in the sparse willow cover, and intensive site preparation would have provided little benefit. Most of the species to be planted were at least moderately shade tolerant. The target planting density was 747 trees ha-1 $\left(303 \mathrm{ac}^{-1}\right)$, on a square spacing of $3.66 \mathrm{~m}(12 \times 12 \mathrm{ft})$. Three sections, totaling $11.6 \mathrm{ha}$, were planted in February and March of 1993. These were separated by control strips $60 \mathrm{~m}$ in width. Approximately 8,700 trees were planted in this section. The 5 species used were 
WSRC-TR-99-00407

October 25, 1999

cherrybark oak (Quercus pagodaefolia), swamp chestnut oak (Q. michauxii), green ash (Fraxinus pennsylvanica), water tupelo, and bald cypress. All seedlings were purchased from the Central Florida Lands and Timber Nursery, Mayo, FL. Seed sources were reportedly in southern Georgia. The seedlings were 1-0 bare root, averaging about 80 $\mathrm{cm}$ in height. Roots were dipped with a water-retaining gel (Agrosoke ${ }^{\mathrm{TM}}$ ) in the field before planting.

\section{Winter 1993-94}

Only the upper corridor was planted in 1994, after applying a wetland-approved herbicide to control dense willow competition and burning to clear brush and vines. Seedlings were produced from seeds collected under contract for the Forest Service from the South Carolina Coastal Plain.

In the upper corridor, a virtually unbroken willow thicket intertwined with blackberry and other vines had developed by the early 1990's. Little light penetrated to the forestfloor, which appeared unsuitable for the growth of even shade-tolerant trees. In order to moderate competition and improve access for planting crews, sections of the upper corridor to be planted were prepared by aerial herbicide application and prescribed burning. The herbicide Rodeo ${ }^{\mathrm{TM}}$ (Monsanto Co., St. Louis, MO) was applied aerially on September 18, 1993 by a helicopter equipped with a microfoil boom, which was designed to produce negligible drift, to apply the herbicide immediately above the 
WSRC-TR-99-00407

October 25, 1999

canopy. Rodeo was applied at the recommended rate of 5.8 liters ha-1 $\left(5 \mathrm{pts} \mathrm{ac}^{-1}\right)$.

Boundaries between control strips and planted areas were marked for easy visibility to the pilot. The herbicide application controlled 95 to $100 \%$ of the willows, with a few small isolated areas missed by the spraying. The herbicide was also highly effective against button bush and wax myrtle. Most red maples were resistant to the herbicide and survived.

In late November of 1993, the 3 sections of the upper corridor to be planted - where the herbicide had been previously applied - were burned. Burning cleared 70 to $80 \%$ of the understory, rendering the upper corridor easily accessible to planting crews. A blackened, ash forest floor resulted in most areas. Fire was often stopped by streams, trails, and wet depressions, so personnel moved throughout the area igniting the understory with drip torches where needed. Using a bulldozer, fire lines were extended from the control strip boundaries to the roads paralleling Pen Branch to prevent fire spreading in the understory of adjacent hardwood stands.

Site preparation radically altered the appearance of the upper corridor, producing a savanna-like.condition with scattered surviving maple 5-10 $\mathrm{m}$ in height and a lush understory. Woody debris fell into backwater channels and sloughs. In the summers of 1994 and 1995, aquatic macrophyte densities appeared to increase dramatically in the upper corridor and downstream, perhaps in response to both greater light availability and nutrient fluxes from the cleared area. 
The target planting density in the upper corridor was 747 trees ha-1 $\left(303 \mathrm{ac}^{-1}\right)$, on a square spacing of $3.7 \mathrm{~m}(12 \mathrm{ft})$. Three sections, totaling $18.3 \mathrm{ha}$, were planted from Dec 27,1993 to Jan 4,1994 . These sections were separated by control strips 90 to $120 \mathrm{~m}$ in width. A total of about 13,700 trees was planted. The 6 major species planted were swamp chestnut oak, cherrybark oak, water oak (Q. nigra), water hickory (Carya aquatica), green ash, and persimmon (Diospyros virginiana). Small quantities of swamp tupelo (Nyssa sylvatica var. biflora), water tupelo, and bald cypress were also planted.

All seedlings planted in 1993-94 originated from seed collected on the South Carolina Coastal Plain. The majority were grown at the Georgia Forestry Commission's Flint River nursery. All seedlings were 1-0 bare root. They were stored at the Savannah River Forest Station in a refrigerated cooler and transported to the field on an open trailer covered with a tarp.

Unfortunately, clearing and burning the understory appeared to induce severe herbivory of the seedlings by feral hogs (Mayer et al., 1999). In many areas, virtually all of the freshly burned ground was rooted. The feral hogs also browsed along the rows of seedlings, uprooting them, and biting off the tap roots. A survey conducted the following spring would show that over $2 / 3$ of the planted seedlings, and nearly all of the oaks, were lost before the beginning of the first growing season. Severe feral hog herbivory occurred exclusively in burned areas and has not been a significant problem 
WSRC-TR-99-00407

October 25, 1999

elsewhere. Recovery of the herbaceous understory in the following growing season provided cover for seedlings and ameliorated herbivory. Feral hog activity has not been a significant problem since.

\section{Winter 1994-95}

The delta was planted in 1995, the upper corridor was replanted, and the lower corridor was inter-planted to compensate for mortality. Site preparation was limited to applying herbicide in about 12 ha of the delta where there were dense willow thickets.

By the early 1990 's, heavy willow thickets had developed on alluvial deposits and channel levees at the mouth of Pen Branch, in the north-central and northwestern parts of the delta. It was felt that a herbicide application here would be advantageous for the growth of cypress and tupelo. In late September of 1994, herbicide was applied in the delta's central planting strip (area $\mathrm{O}$, figure 1 ) and portions of the western-most planting section (area $Q$, figure 1), keeping well clear of natural regeneration near the fringe. The spray area was marked for high visibility from the air with large plastic flags attached to the top of bamboo poles. The contractor and aircraft were the same as in the previous year. The tank mixture was the same as that of the previous year, except that Rodeo was applied at the rate of 4.7 liters ha-1 $\left(4 \mathrm{pts} \mathrm{ac}^{-1}\right)$. 
WSRC-TR-99-00407

October 25, 1999

The treatment was 90 to $100 \%$ effective against willows in the central planting strip. In the more poorly drained western planting section, however, the herbicide was less effective. Poor drainage may have diminished the herbicide's efficacy or the coverage may have been uneven. In this area, the aircraft was forced to fly about 30 to $50 \mathrm{~m}$ above the canopy to avoid cypress snags. Aerial photos and ground reconnaissance showed an abrupt, clear boundary of willow mortality at the edge of the intended spray area.

The target planting density for most of the delta was 1078 trees ha-1 $\left(436 \mathrm{ac}^{-1}\right)$ on a square spacing of $3 \mathrm{~m}$ (10 ft). In the southeastern delta, however, 4.9 ha were conceded to the contractor as unplantable by a normal hand-planting crew. This area (part of $M$, Figure 1) was later planted by Forest Service personnel at an approximate spacing of $3 x$ $6 \mathrm{~m}(10 \times 20 \mathrm{ft})$ and density of about 500 trees ha-1. It was characterized by deep, unconsolidated muck soils and standing water. Some parts were reached using snow shoes, and favorable microsites were chosen for planting. Because of its exceedingly poor drainage, this area will probably support only a sparse tree canopy with some open water. About 35,000 trees were planted on a total of 34.6 ha in the delta. The 3 species planted were water tupelo, bald cypress, and green ash. The ash were confined to better drained willow ridges. The planting was performed from mid-January to midFebruary of 1995 . Seedlings were inserted directly into the muck or dibble planted with a shovel. 
WSRC-TR-99-00407

October 25, 1999

Feral hog herbivory and other sources of mortality left only 230 of the 747 trees ha-1 originally planted in the upper corridor by the start of the first growing season. This density, especially with future mortality, was inadequate for the development of a closed canopy forest. Therefore, the upper corridor was inter-planted with an additional 1078 trees $\mathrm{ha}^{-1}$ on a square spacing of $3.0 \mathrm{~m}(10 \mathrm{ft})$. Assuming that the target planting density was achieved, a total of 19,800 trees were added. The 8 species planted were cherrybark oak, water oak, green ash, sycamore (Platanus occidentalis), pignut hickory (Carya glabra), shumard oak (Q. shumardii), water hickory, and swamp tupelo.

Although 476 of the 747 trees ha-1 originally planted in the lower corridor remained after the first growing season, an additional 549 were added to compensate for future mortality and bring stocking in all areas to similar levels. Assuming that the desired density was planted, a total of 6,300 seedlings were added. The density of newly planted seedlings on 23 inspection plots in this area averaged $627 \mathrm{ha}^{-1}, 14 \%$ over the objective. The 5 species planted were bald cypress, green ash, cherrybark oak, water tupelo, and swamp tupelo.

All seedlings planted in 1994-95 were 1-0 bare-root grown from locally collected seed sources, except for 6,000 2-0 bald cypress. The 2-0 cypress were purchased from inventory of the Flint River Nursery that had been unsold the previous year, and were from a southern Georgia seed source. These larger seedlings were purchased to accommodate deep water areas and the severe herbaceous competition of the delta. 
WSRC-TR-99-00407

October 25, 1999

Seedlings were transported to the work site in the bed of a pickup truck and were well covered by a reflective tarp prior to planting.

\section{REGENERATION STOCKING SURVEYS}

The limited objective of this monitoring effort was to quantify the abundance and size of desirable regeneration, artificial or natural, in the planted and control areas.

Desirable species were defined as those typically present as large canopy trees in bottomland-hardwood and cypress-tupelo forests. Specifically excluded were black willow, black alder, button bush, and wax myrtle, which were present at undesirably high densities. Others species such as sumac were excluded because they are minor or atypical components in mature bottomland-hardwood forests. The initial survey was conducted in 1994, with more intensive surveys conducted in 1996 and 1997.

In the 1994 survey, sixty-six circular plots, 0.04 ha $(0.1 \mathrm{ac})$ in area, were established randomly throughout the upper and lower corridor - with four plots in each control section and variable numbers in the planted sections, depending upon their planted acreage. No plots were established in the delta, as it had not yet been planted at the time of the survey.

The vegetation plots were measured in the spring of 1994 . On each plot, all planted trees were marked with red pin flags. Volunteers of desirable species were marked 
WSRC-TR-99-00407

October 25, 1999

with blue and white, striped flagging tape. Volunteers were defined as species that had not previously been planted in the section. The plot center was marked with an aluminum pole. The top of each pole was painted orange, and a metal tag with the plot number was attached to each pole. The number of planted and volunteer trees on each plot was recorded by species. The current height and estimated height at the time of planting were recorded for each species. Abundance of desirable regeneration by treatment area, species, and origin--planted or volunteer--was calculated with the FREQ procedure of SAS statistical software (SAS Institute, 1990).

The spring 1994 survey revealed severe losses to feral hog herbivory in planted sections of the upper corridor (Figure 5). The mean density of 285 planted and volunteer trees per hectare was probably insufficient to support the development of a closed canopy forest-especially when allowing for future mortality. About $17 \%$ of the upper corridor had no remaining planted trees. These results lead to our decision to replant this area in 1995.

This survey also showed that sparse natural regeneration of a few desirable species was a small, but potentially important contribution to stand development. There were approximately 37 red maple stems ha- ${ }^{-1}$ in planted sections of the upper corridor, and another 17 stems ha-1, consisting of sweetgum (Liquidambar styraciflua), sycamore, red bay (Persia borbonia), laurel oak (Q. laurifolia), and loblolly pine (Pinus taeda). All of these occur to some extent in bottomland forests and will complement the suite of planted 
WSRC-TR-99-00407

October 25, 1999

species. Natural regeneration was less abundant in planted sections of the lower corridor, which were more poorly drained. Virtually all volunteers in the lower corridor, only $20 \mathrm{ha}^{-1}$ total, were red maples, with a few scattered pines. No other desirable species were found in the lower corridor.

A follow-up survey that also included the delta was conducted in the spring of 1996 (Kolka and Trettin, 1997). It was intended to assess the survival of the initial delta planting and the replanting success of the corridor. During this survey, a total of 151 plots were measured throughout the restoration area. As in the earlier survey, all desirable species were recorded in each plot and analyzed within each of the designated areas. Results of the survey indicated good survivalship of planted seedlings with all section means in the planted areas over the desired level of 500 trees ha-1 set by the Forest Service (Table 3). Approximately $12 \%$ of the seedlings were volunteers from species that had not been planted. Variability among plots was examined and a larger survey was designed to more accurately reflect the actual stocking of the restoration the following year.

In the spring of 1997 , a total of 528 circular 0.008 hectare plots were measured in the planted and unplanted areas of the corridor and delta. An additional 63 plots were measured in the natural regeneration areas around the delta perimeter. As in prior surveys, stocking level of desirable species in all the planted areas was determined from these plots. Planted areas in the upper corridor averaged 401 trees ha $^{-1}$, the lower 
WSRC-TR-99-00407

October 25, 1999

corridor 405 trees ha-1, and the delta 522 trees $\mathrm{ha}^{-1}$. These seedling establishment rates fall within the range of 300 to 900 stems per hectare reported for densities in unimpacted bottomland systems for the region (Megonigal et al., 1997). In the 1996 survey, the planted and naturally regenerating delta regions were considered together. In the 1997 survey, they were considered separately, thus accounting for the drop in the delta stocking. The density of the naturally regenerating area around the delta was highly variable, but averaged 1750 seedlings per hectare. From the survey results, it appears that bald cypress is established throughout the floodplain and delta with water tupelo and green ash performing well in the wetter lower corridor and delta. Swamp chestnut oak and persimmon, species more typical of somewhat less inundated bottomland hardwood conditions, are surviving well in the drier upper corridor. Species diversity reflects the species planted as well as the early successional volunteers that have seeded in. It appears that the future Pen Branch forest canopy will be similar in composition to the pre-disturbance canopy (Sharitz et al., 1974).

\section{SUMMARY}

From the results of the regeneration surveys, it appears that Pen Branch is on a course towards becoming a mixed bottomland hardwood system in the corridor regions and a cypress-tupelo swamp in the delta regions. Stocking levels are similar, or slightly greater, than unimpacted areas of similar habitat type on the SRS. The results of tree planting can be seen soon after the restoration effort, however, because of the longevity 
WSRC-TR-99-00407

October 25, 1999

of tree species, the long-term success will require many more years to confirm.

Continued monitoring of the vegetation will be necessary to document the continued development of the community since it is still in the early stages of restoration. The point-in-time where the system becomes self-sustaining is the end-point of the restoration.

There have been relatively few bottomland hardwood restoration projects of this size in the southeast and none that have started with post-disturbance conditions as severe as those in Pen Branch. While the early information indicates that the primary objective of the restoration is being met, the information provided by the research on different components of the ecosystem show that we have done more than re-establish tree species. As shown by the breadth of research that will be reported during this workshop on the Pen Branch corridor and delta, the focus is on the assessment of ecosystem level processes that are occurring as restoration and succession proceed. The physical layout of the control and restored strips, along with the ecological gradient from the upper riparian corridor to the delta swamp, have provided an excellent research vehicle for investigations into many disciplines. These studies are providing data on productivity and biodiversity of many of the biotic components of the system. In many cases, diversity and productivity are above expected reference values. Other studies are looking at the abiotic components of the system to describe the return of biogeochemical functions to the restored ecosystem. Most indicate that in addition to the establishment of a wetland forest, we are also returning many of the other normal 
WSRC-TR-99-00407

October 25, 1999

wetland functions to the Pen Branch ecosystem. Many of these studies are included in this volume.

Comparisons of populations and processes across successional gradients and treatments have allowed the effect of disturbance and restoration activities to be evaluated. Knowledge gained from these studies will enable future restoration efforts to be more efficiently and effectively performed and evaluated. For restoration to be considered effective, wetland functions need to be restored or at least on a trajectory where restoration of those functions is probable. To develop easily measurable indicators of wetland functions that will predict future conditions, interactions between abiotic and biotic processes need to be investigated. With the integration of the results of monitoring and research, we are beginning to get a better picture of the biotic and abiotic parameters that have the most promise as wetland function indicators.

\section{ACKNOWLEDGEMENTS}

This research was funded by DOE contract number DE-AC09-96SR18500. Numerous technicians and field personnel were indispensable in getting the study area installed and ready for the research effort that was to follow. To all those who have participated, a heart-felt thank you. 
WSRC-TR-99-00407

October 25, 1999

\section{REFERENCES CITED.}

Christensen, E.J., M.E. Hodgson, J.R. Jensen, H.E. Mackey, and R.R. Sharitz. Pen Branch delta expansion. Environmental Sciences Division, DuPont Savannah River Laboratory. DPST83-1087, 1984; $19 \mathrm{p}$.

Department of Energy. Record of decision: continued operation of K, L, and P Reactors, Savannah River Site, Aiken, SC. Federal Register, 1991; 56(28):5584-5587.

Kolka, R.K. and C.C. Trettin. Wetlands research related to the Pen Branch restoration effort on the Savannah River Site. 1996 Annual Report. Westinghouse Savannah River Company, WSRC-TR-97-00273, 1997; $24 \mathrm{p}$.

Mayer, J.J., E.A. Nelson, and L.D. Wike. Selective depredation of planted hardwood seedlings by wild pigs in a wetland restoration area. Sci. of the Total Envir, 1999; this issue.

Menonigal, J.P., W.H. Conner, S. Kroeger, and R.R. Sharitz. Aboveground production in Southeastern floodplain forests: A test of the subsidy-stress hypothesis. Ecology, 1997; 78:370-384.

Monsanto Company. Rodeo aquatic herbicide: complete directions for use in aquatic and other sites. Monsanto Company Agricultural Products, St. Louis, Missouri, 1990. 
WSRC-TR-99-00407

October 25, 1999

Nichols, D.M. Program implementation plan for mitigation action plan: 1992 annual update.

Westinghouse Savannah River Company, Reactor Environmental Management, Aiken, SC. RRD-OAM-911515, 1992.

SAS Institute. SAS procedures guide, version 6, third edition. SAS Institute Incorporated, Cary, NC., 1990.

Sharitz, R.R., J.E. Irwin, and E.J. Christy. Vegetation of swamps receiving reactor effluents. Oikos, $1974 ;$ 25:7-13.

Sharitz, R.R. and L.C. Lee. Limits on regeneration processes in southeastern riverine wetlands. In riparian ecosystems and their environment: reconciling conflicting uses. First North American conference, April 16-18, 1985, Tucson, Arizona. General technical report RM-120, Rocky Mountain Forest and Range Experiment Station, USDA Forest Service, Ft. Collins, CO.,1985; pp. 139-160.

Wike, L.D, R.W. Shipley, J.A. Bowers, A.L. Bryan, C.L. Cummins, B.R. del Carmen, G.P. Friday, J.E. Irwin, H.E. Mackey, Jr., J.J. Mayer, E.A. Nelson, M.H. Paller, V.A. Rogers, W.L. Specht, and E.W. Wilde. SRS ecology: environmental information document. Westinghouse Savannah River Company, Aiken, SC., WSRC-TR-93-496, 1994. 
TABLE 1. DESCRIPTION OF THE PRIMARY TREATMENT ZONES FOR THE PEN BRANCH RESTORATION.*

\begin{tabular}{|c|c|l|}
\multicolumn{1}{c}{ Zone } & $\begin{array}{l}\text { Area } \\
\text { (ha) }\end{array}$ & Description \\
\hline $\begin{array}{c}\text { Upper } \\
\text { Corridor }\end{array}$ & 24.1 & $\begin{array}{l}\text { Mesic bottomland. Water table typically at a depth of } 30 \text { to } \\
80 \mathrm{~cm} \text { during the growing season. One or two well defined } \\
\text { stream channels. To be planted with mixed bottomland } \\
\text { hardwoods. Initially occupied by dense, virtually unbroken } \\
\text { willow thickets. }\end{array}$ \\
\hline $\begin{array}{c}\text { Lower } \\
\text { Corridor }\end{array}$ & 15.3 & $\begin{array}{l}\text { Poorly drained bottomland. Water table within } 20 \text { or } 30 \mathrm{~cm} \\
\text { of the soil surface during the growing season. Braided, } \\
\text { unstable stream with up to } 4 \text { or } 5 \text { water courses. To be } \\
\text { planted with mixed bottomland hardwoods, bald cypress, } \\
\text { and water tupelo. Initially occupied by scattered willow } \\
\text { thickets and frequent grassy openings where soils were too } \\
\text { wet to support wood vegetation. }\end{array}$ \\
\hline Delta & 46.0 & $\begin{array}{l}\text { Swamp. Continuously flooded, except on sandy ridges near } \\
\text { the mouth of Pen Branch, where water table remains within } \\
\text { 20 cm of the soil surface. To be planted with bald cypress } \\
\text { and water tupelo, with some green ash on better drained } \\
\text { ridges. Initial cover: about 2/3 cattail or cattail-bulrush } \\
\text { mixture, and about 1/3 scattered willow ridges. }\end{array}$ \\
\hline
\end{tabular}

* Boundaries shown in Figure 1. 
WSRC-TR-99-00407

October 25, 1999

Table 2. Site preparation and planting summary for the Pen Branch restoration.

\begin{tabular}{|c|c|c|}
\hline Location & Site Preparation* & Planting \\
\hline $\begin{array}{l}\text { Upper } \\
\text { Corridor }\end{array}$ & $\begin{array}{l}\text { Aerial herbicide application to } \\
\text { control willows in September } \\
\text { of } 1993 . \\
\text { Burned to improve access for } \\
\text { planting crews in November } \\
\text { of } 1993 .\end{array}$ & $\begin{array}{l}\text { Planted } 747 \text { trees ha-1 }\left(303 \mathrm{ac}^{-1}\right) \text { in } \\
\text { December of } 1993 \text { and January of } \\
1994 . \\
\text { Planted an additional } 1078 \text { trees } \\
\text { ha-1 }\left(436 \mathrm{ac}^{-1}\right) \text { to compensate for } \\
\text { mortality in January of } 1995 .\end{array}$ \\
\hline $\begin{array}{l}\text { Lower } \\
\text { Corridor }\end{array}$ & None. & $\begin{array}{l}\text { Plant } 747 \text { trees ha-1 }\left(303 \mathrm{ac}^{-1}\right) \text { in } \\
\text { February and March of } 1993 . \\
\text { Planted an additional } 549 \text { trees } \\
\text { ha }^{-1}\left(222 \text { ac }^{-1}\right) \text { in January and } \\
\text { February of } 1995 .\end{array}$ \\
\hline Delta & $\begin{array}{l}\text { Herbicide application to } \\
\text { control willow on levees and } \\
\text { alluvial deposits (12 ha) in } \\
\text { September of } 1994 .\end{array}$ & $\begin{array}{l}\text { Planted } 1078 \text { trees ha-1 }\left(436 \mathrm{ac}^{-1}\right) \text {, } \\
\text { with } 4.9 \text { ha planted at about } 500 \\
\text { ha-1 due to deep muck and } \\
\text { standing water in January and } \\
\text { February of } 1995 .\end{array}$ \\
\hline
\end{tabular}

* Planted sections only. 
WSRC-TR-99-00407

October 25, 1999

Table 3. Stocking levels for Pen Branch regions during different years (Trees per hectare)

\begin{tabular}{|l|c|c|c|}
\hline LOCATION & 1994 & 1996 & 1997 \\
\hline & & & \\
\hline Upper Corridor & 285 & 717 & 401 \\
\hline & & & \\
\hline Lower Corridor & 496 & 556 & 405 \\
\hline & & & \\
\hline Planted Delta & & 1508 & 522 \\
\hline & & & \\
\hline Natural Delta & & & 1750 \\
\hline
\end{tabular}


WSRC-TR-99-00407

October 25, 1999

Figure Captions

Figure 1. Location and research design of the Pen Branch Restoration Project.

Figure 2. Average annual flow rate and temperature of K-Reactor effluent. Temperature data not available for 1985 to present. Adapted from Wike et al. (1994).

Figure 3. Pen Branch delta expansion of thermal damage to vegetation. Composite image, 1961-1982 (from Christensen et al., 1984).

Figure 4. Hydrological gradient in Pen Branch regions from 1993-1995 (+/- 1 SD).

Figure 5. Mean densities of desitable regeneration in planted areas of Pen Branch (Spring 1994). 
WSRC-TR-99-00407

October 25, 1999
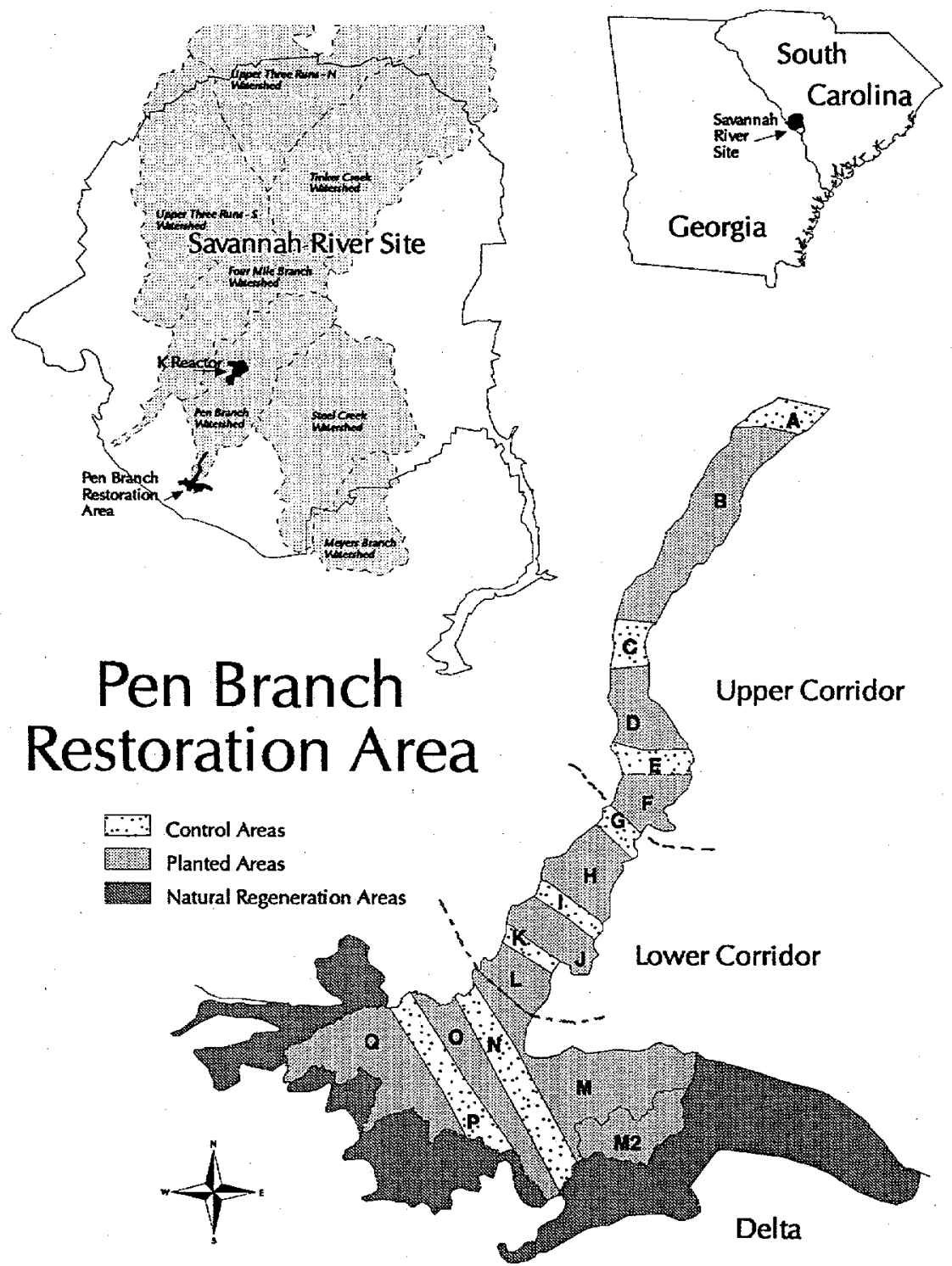
WSRC-TR-99-00407

October 25, 1999

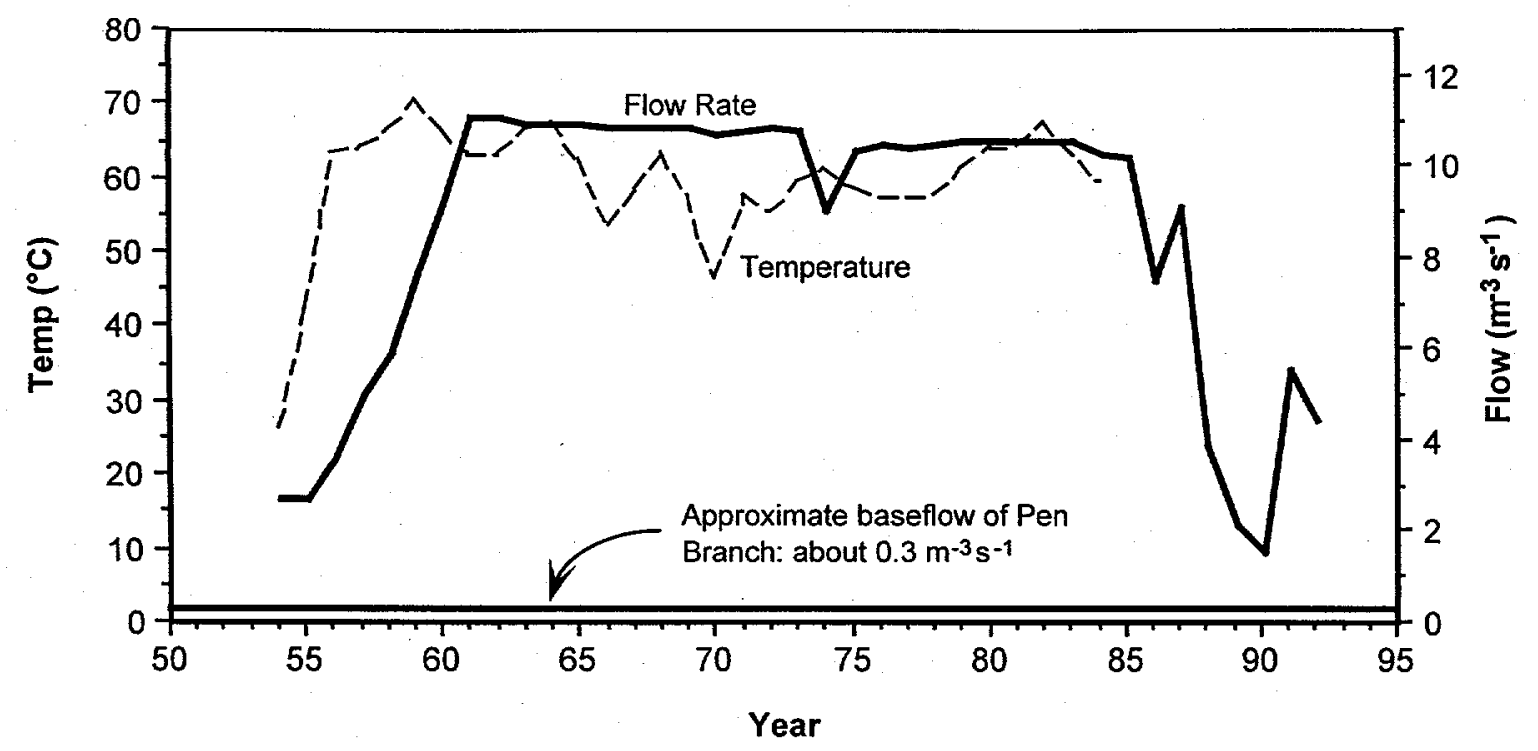




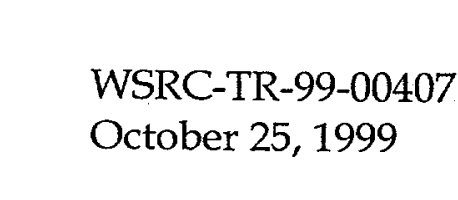

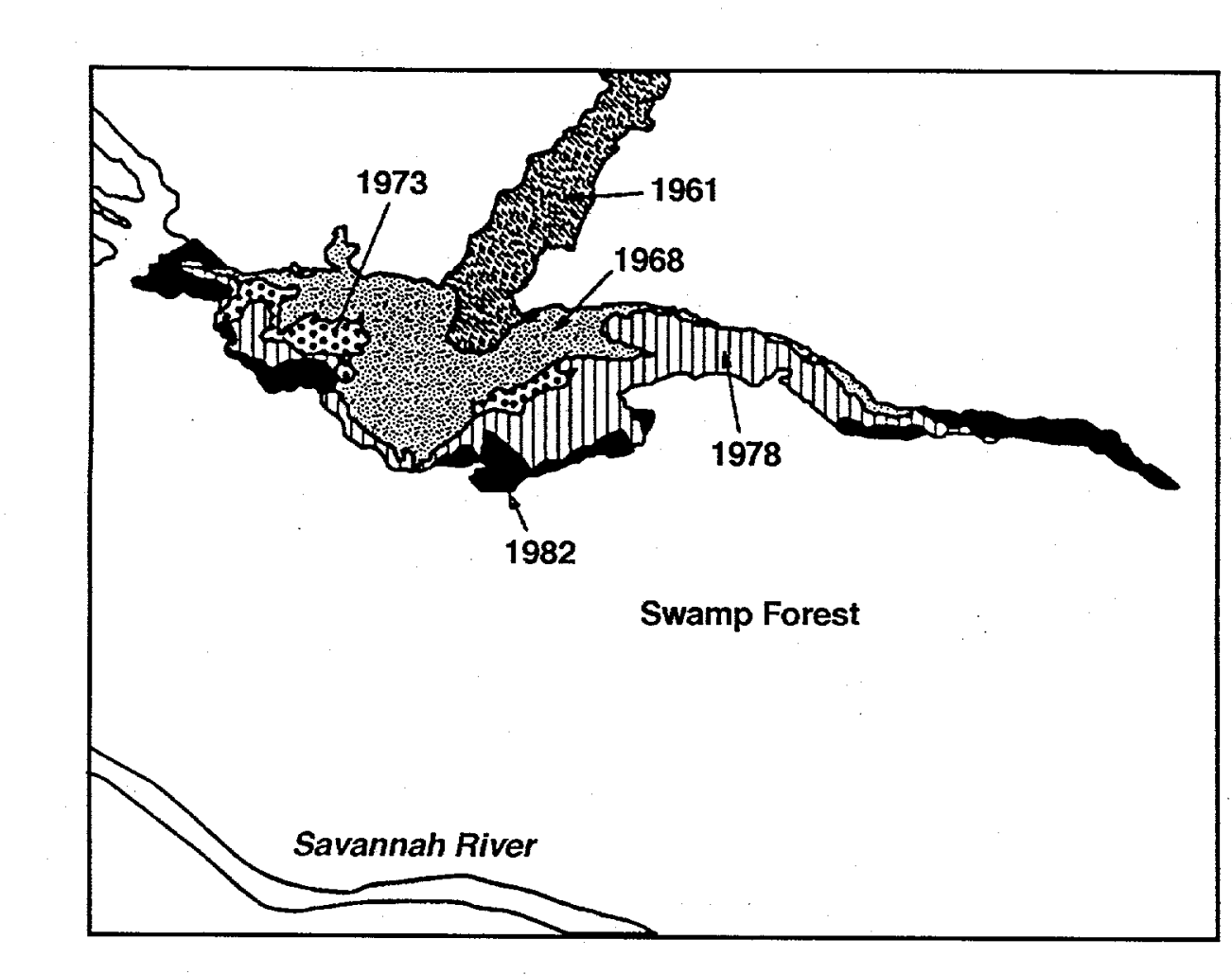


WSRC-TR-99-00407

October 25, 1999

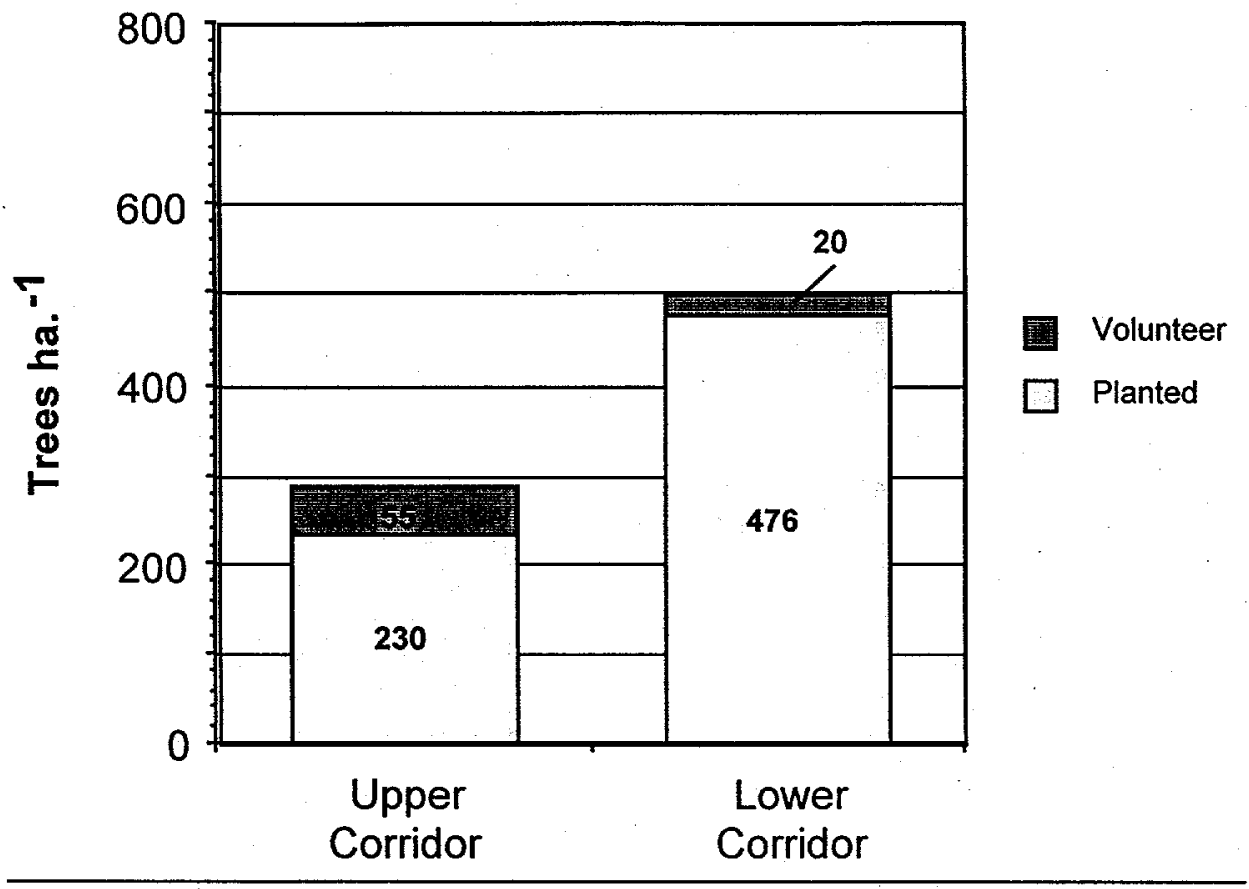


WSRC-TR-99-00407

October 25, 1999

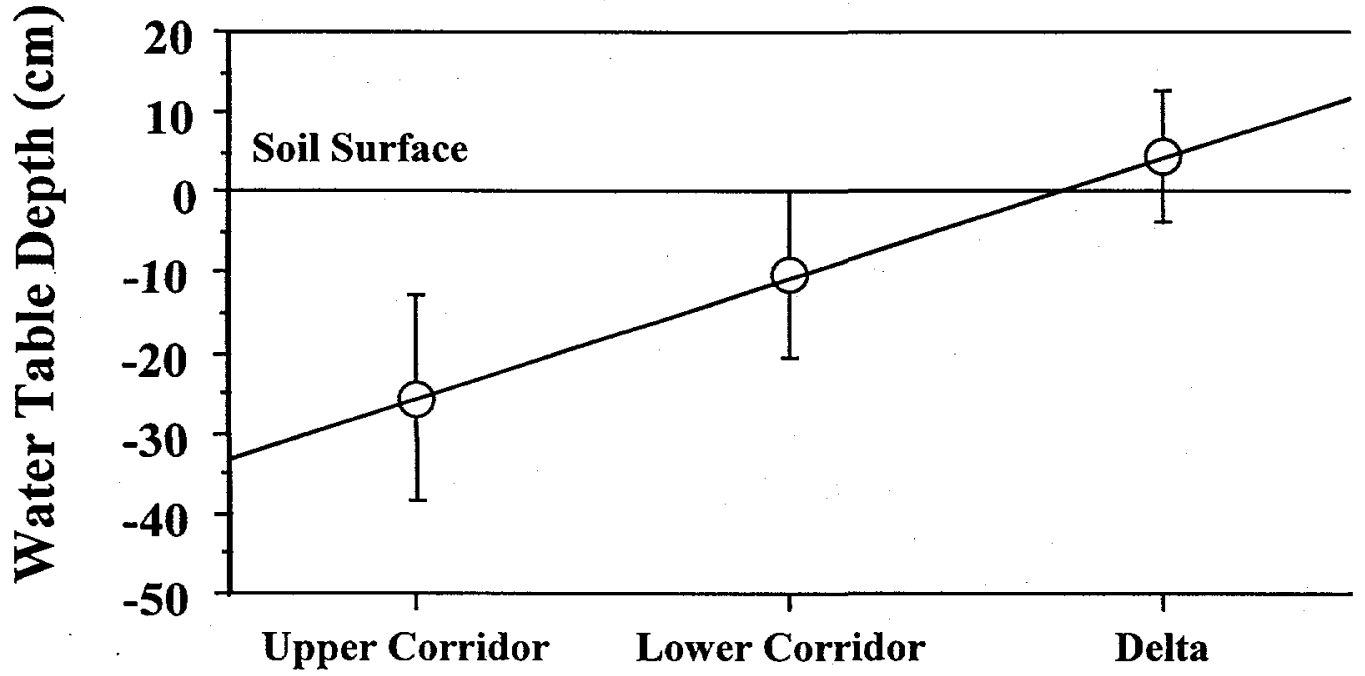

